\title{
Molybdenum isotope behaviour accompanying weathering and riverine transport in a basaltic terrain
}

\author{
Christopher R. Pearce a,*, Kevin W. Burton ${ }^{\text {a,1 }}$, Philip A.E. Pogge von Strandmann ${ }^{\text {a,2 }}$, \\ Rachael H. James ${ }^{\mathrm{a}, 3}$, Sigurður R. Gíslason ${ }^{\mathrm{b}}$ \\ a Department of Earth and Environmental Sciences, The Open University, Walton Hall, Milton Keynes, MK7 6AA, UK \\ ${ }^{\mathrm{b}}$ Institute of Earth Sciences, University of Iceland, Sturlugata 7, 101 Reykjavík, Iceland
}

\section{A R T I C L E I N F O}

\section{Article history:}

Received 8 April 2009

Received in revised form 19 March 2010

Accepted 21 March 2010

Available online 28 April 2010

Editor: M.L. Delaney

\section{Keywords:}

molybdenum (Mo) isotopes

basaltic weathering

riverine inputs

estuarine mixing

\begin{abstract}
A B S T R A C T
The application of the molybdenum (Mo) isotope system as a proxy for determining changes in the redox state of the oceans is predicated on the assumption that the composition of continental input can be characterised from crustal rock types, and remains constant. However, it has recently been shown that the $\delta^{98 / 95}$ Mo composition of global rivers varies between $0.15 \%$ and $2.4 \%$ and is therefore systematically heavier than the average composition of the continental crust $(\sim 0 \%)$. In order to understand the processes that control Mo-isotope fractionation during weathering this study presents $\delta^{98 / 95}$ Mo and Mo abundance data for rivers (and estuarine samples) from Iceland that drain predominantly basaltic terrains. Resolvable differences are observed in the isotopic composition of the riverine Mo sources; ice $\left(\delta^{98 / 95} \mathrm{Mo}_{\text {ice }}>1.8 \%\right.$ ), basaltic bedrock $\left(\delta^{98 / 95} \mathrm{Mo}_{\text {bedrock }} \sim 0.0 \%\right.$ o) and hydrothermal waters $\left(\delta^{98 / 95} \mathrm{Mo}_{\text {hydrothermal }} \sim-3.4 \%\right.$ ). Systematic changes in the dissolved Mo-isotope composition are also observed within river catchments, with $\delta^{98 / 95} \mathrm{Mo}$ values increasing from $\sim 0 \%$ in glacial rivers (close to the source) to $\sim 1 \%$ o downstream, consistent with Mo-isotopes being fractionated during weathering. Analysis of other riverine phases (bedload, colloids and iron-precipitates) demonstrates that these phases preferentially incorporate light Moisotopes, and remain coupled to the dissolved load during riverine transportation. A $\delta^{98 / 95}$ Mo profile through the Borgarfjörður estuary exhibits a predominantly conservative mixing behaviour, but suggests that the release of isotopically light Mo from the particulate and/or colloidal phases may occur in the low salinity part of the estuarine mixing zone.
\end{abstract}

(c) 2010 Elsevier B.V. All rights reserved.

\section{Introduction}

Molybdenum (Mo) is one of the most abundant transition metals in the oceans and is important for a range of biological and geochemical processes (e.g. Manheim and Landergren, 1974; Colodner et al., 1995; Morford and Emerson, 1999; Anbar, 2004). Of particular interest is the highly redox-sensitive behaviour of Mo that is accompanied by significant isotope fractionation, which results in oxic, suboxic, anoxic and euxinic sediments possessing isotopically distinct Mo-isotope compositions (Barling et al., 2001; Barling and Anbar, 2004; Siebert et al., 2003, 2006; Poulson et al., 2006; Neubert et al., 2008a). Consequently variations in $\delta^{98 / 95} \mathrm{Mo}$ can be utilised as a palaeoredox proxy, and have been used to demonstrate the expansion of reducing marine conditions

\footnotetext{
* Corresponding author.

E-mail address: c.pearce@open.ac.uk (C.R. Pearce).

1 Present address: Department of Earth Sciences, Oxford University, Parks Road, Oxford, OX1 3PR, UK.

2 Present address: Bristol Isotope Group, University of Bristol, Wills Memorial Building, Queen's Road, Bristol, BS8 1RJ, UK.

${ }^{3}$ Present address: National Oceanography Centre, University of Southampton Waterfront Campus, European Way, Southampton, SO14 3ZH, UK.
}

at a number of times throughout Earth's history (e.g. Arnold et al., 2004; Siebert et al., 2005; Wille et al., 2007; Pearce et al., 2008). A critical assumption in the application of the Mo-isotope redox proxy in this manner is that the isotope composition of Mo entering the oceans has remained more-or-less constant throughout geological history, and that the net Mo isotope composition of weathered continental material input to the oceans is similar to the mean composition of the continental crust (e.g. Siebert et al., 2003; Anbar, 2004; Arnold et al., 2004). However, recent measurements of a number of globally significant rivers have shown that the $\delta^{98 / 95}$ Mo composition of Mo entering the oceans varies significantly, and displays a range similar to that observed in all geological samples analysed to date (between $0.15 \%$ and $2.40 \%$; Archer and Vance, 2008). Therefore, identifying and understanding the processes that result in Mo fractionation during weathering and riverine transport, in addition to precisely defining the isotope composition of other oceanic Mo sources, is essential for the quantitative application of this isotope system to study past changes in ocean redox chemistry.

This study presents $\delta^{98 / 95}$ Mo data for rivers draining basaltic catchments in Iceland. These catchments are essentially monolithological, consequently there is little isotope variation from the weathering of different rock types. Rather they provide an 
opportunity to study the effects of weathering processes accompanying variations in rainfall, soil, vegetative and glacial cover. The influence of hydrothermal waters and runoff from glacial melting is also assessed. In addition to the dissolved riverine $\delta^{98 / 95}$ Mo compositions, Mo isotope data from bedload particulates, colloids and Feprecipitates have also been obtained in order to quantify the processes that control Mo-isotope fractionation in the riverine environment. A $\delta^{98 / 95}$ Mo profile through the Borgarfjörður estuary in west Iceland (which drains one of the studied catchments) has also been measured to determine the mixing behaviour of Mo in the estuarine environment. These results are compared with those for other stable and radiogenic isotopes measured in the same or related samples from Iceland (e.g. lithium and magnesium; Pogge von Strandmann et al., 2006, 2008a, osmium; Gannoun et al., 2006, silicon; Georg et al., 2007, and uranium-series; Pogge von Strandmann et al., 2006 and Vigier et al., 2006), which provide a framework for understanding the behaviour of the Mo-isotope system.

\section{Geological setting, climate and sample localities}

\subsection{Geological setting and climate}

Iceland sits astride the mid-Atlantic ridge, having been formed by crustal accretion at the diverging lithospheric plates. Therefore, most of the island (80-85\%) is composed of basaltic volcanic rocks, with minor acidic intrusions and volcanoclasitc sediments (Gislason et al.,
1996; Jóhannesson and Saemundsson, 1998). The basalts increase in age from the centre of the island towards its western and eastern edges, with the symmetrical zonation following the SW-NE trend of the Atlantic ridge (Fig. 1). The oldest basalts in the northwest and east are $\sim 13 \mathrm{Ma}$ (Moorbath et al., 1968), whilst the youngest rocks (Quaternary to Recent) are found in the volcanically active zones close to the ridge. The more recently erupted basalts tend to have higher permeabilities, as compaction and the precipitation of secondary minerals reduces the permeability of the older rocks (Sigurdsson and Ingimarsson, 1990; Gislason et al., 1996; Neuhoff et al., 1999). This difference is also reflected in the nature of the water discharge; surface runoff dominates in the older, less permeable areas, whereas there are fewer surface streams in the younger regions, and glacierand spring-fed rivers are more dominant.

The mean annual temperature of Iceland is $4{ }^{\circ} \mathrm{C}$, with a seasonal variability of $15^{\circ} \mathrm{C}$. The climate is oceanic boreal climate with annual precipitation rates that vary from $400 \mathrm{~mm}$ to $4000 \mathrm{~mm}$, with the southeast of the island receiving almost twice the amount of precipitation as the west $(1355 \mathrm{~mm} / \mathrm{yr}$ versus $776 \mathrm{~mm} / \mathrm{yr}$; Georg et al., 2007). The annual discharge of Icelandic rivers is $170 \mathrm{~km}^{3}$ (equating to $\sim 0.45 \%$ of global riverine discharge into the oceans), whilst the total size of the island is $103,000 \mathrm{~km}^{2}$, representing $\sim 0.1 \%$ of the global land area drained to the oceans (Gannoun et al., 2006). The flux of suspended load carried by the Icelandic rivers each year is $0.02-0.025 \mathrm{~km}^{3}$, which is $\sim 0.3 \%$ of the global annual flux to the oceans (Gislason et al., 1996). Some $11,260 \mathrm{~km}^{2}(\sim 11 \%)$ of the island is under

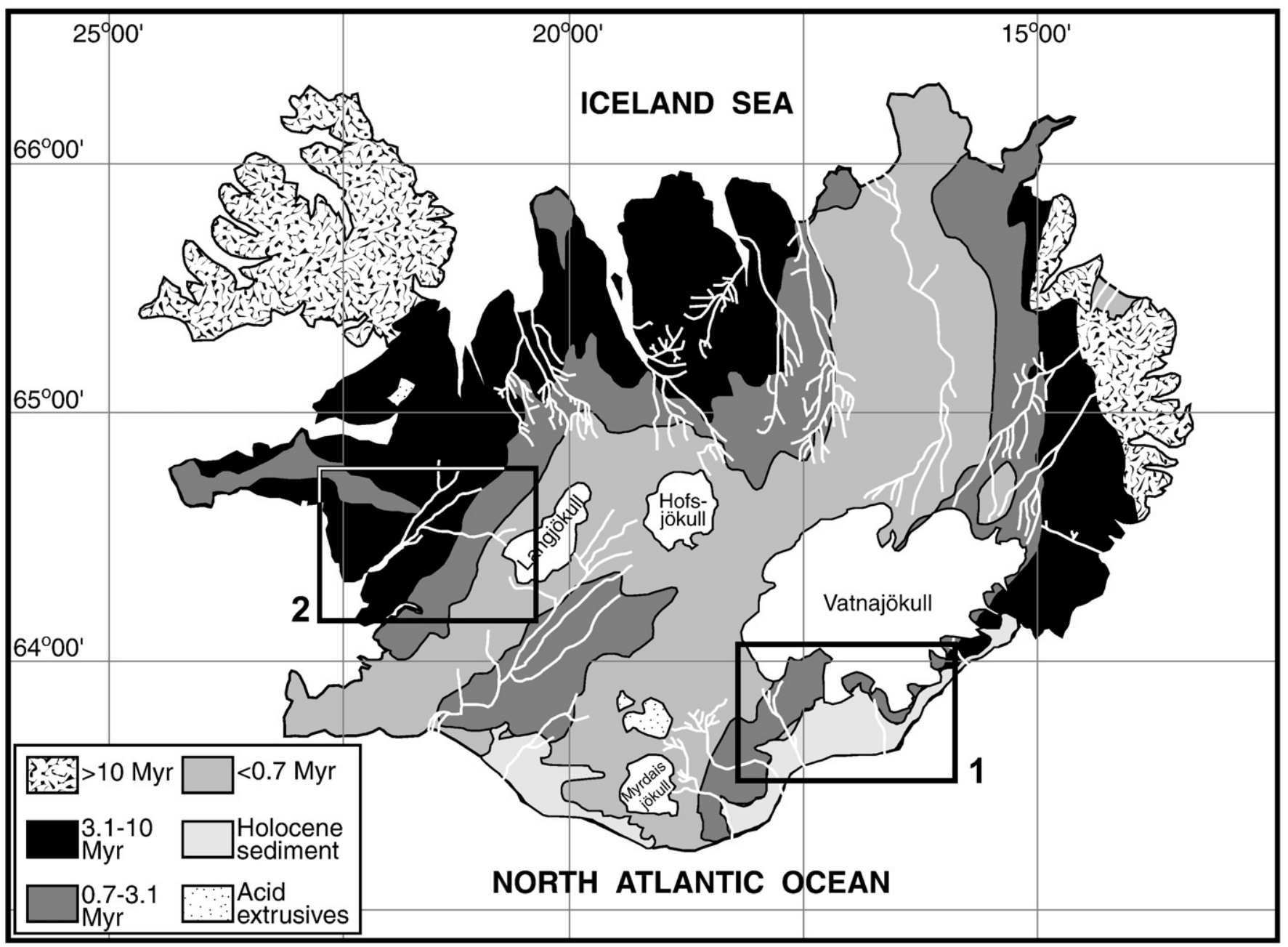

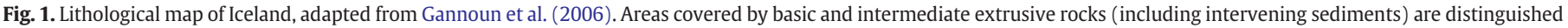

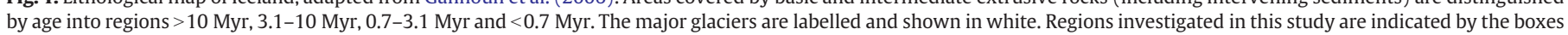
in the southeast (1) and west (2) of Iceland, and are expanded in Figs. 2 and 3 respectively. 
glacial cover, with the largest icecap being the $8300 \mathrm{~km}^{2}$ Vatnajökull glacier in the southeast.

\subsection{Sample localities}

Two different regions in Iceland have been investigated (Fig. 1). Although both regions are predominantly basaltic, they differ in both bedrock age and in the proportion of glacial and vegetation cover, resulting in different rates of physical and chemical erosion. The first area in southeast Iceland (Fig. 2) has bedrock ages ranging from Quaternary to Recent, and has a number of rivers that are sourced directly from the Vatnajökull glacier. Average physical erosion rates for this area are $\sim 2080 \mathrm{t} / \mathrm{km}^{2} / \mathrm{yr}$, whilst the average chemical weathering rates are $152 \mathrm{t} / \mathrm{km}^{2} / \mathrm{yr}$ (Gislason et al., 1996; Pogge von Strandmann et al., 2006). The second region in the west of Iceland (Fig. 3) is underlain by older bedrock (of Tertiary age; 3.1 Ma), and is dominated by the Hvitá river that is partially sourced by the Langjökull glacier. This catchment area includes several non-glacial tributaries and is more vegetated than the southeast region. The average physical erosion rates are $1090 \mathrm{t} / \mathrm{km}^{2} / \mathrm{yr}$, and average chemical weathering rates are $72 \mathrm{t} / \mathrm{km}^{2} / \mathrm{yr}$ (Pogge von Strandmann et al., 2006). The western Iceland catchment area drains into the Borgarfjörður estuary, which is $25 \mathrm{~km}$ long and up to $5 \mathrm{~km}$ wide (Fig. 3, inset). The estuary is tidally dominated and well mixed both vertically and horizontally, with water depths that range from 1 to $2 \mathrm{~m}$ in the innermost $5 \mathrm{~km}$ increasing rapidly to $\sim 100 \mathrm{~m}$ by $10 \mathrm{~km}$ (Pogge von Strandmann et al., 2008b). Precise sample locations are shown in Figs. 2 and 3, and are given in Tables 1 and 2.

\section{Sampling methods and analytical techniques}

\subsection{Sampling methods}

Samples were collected in September 2003 and August 2005 (Pogge von Strandmann et al., 2006, 2008b). River samples were taken using pre-cleaned bottles from the centre of the flow, whilst estuarine samples were collected by boat from $\sim 1 \mathrm{~m}$ below the water surface using pre-cleaned $10 \mathrm{l} \mathrm{Go-Flo} \mathrm{bottles.} \mathrm{At} \mathrm{all} \mathrm{sites} \mathrm{in} \mathrm{situ} \mathrm{measurements} \mathrm{of}$ $\mathrm{pH}$, temperature, conductivity and total dissolved solid (TDS) content were also made. Each water sample was filtered on the day of collection through a $0.2 \mu \mathrm{m}$ cellulose acetate filter using a pressurised Teflon unit, to ensure the dissolved load was separated from the suspended load. The total suspended solid (TSS) content was determined using the weight difference of the $0.2 \mu \mathrm{m}$ filter after a known volume of water had been filtered. The colloidal fraction $(>10 \mathrm{kD})$ was collected by subsequent ultrafiltration of the dissolved load using a Sartorius crossflow filter with Sartocon polyethersulphone (PESU) slice cassettes. For some samples, $15 \mathrm{l}$ of filtered water was co-precipitated using an ultrapure iron-oxyhydroxide solution. Although artificial, the resulting ironprecipitates provide an analogue for natural $\mathrm{Fe}-\mathrm{Mn}$ oxides that form in the river system. Riverine bedload samples were taken where possible, and have been found to contain a mixture of unweathered material and secondary clay phases (Pogge von Strandmann et al., 2006). Further details on the collection and previous analyses of these samples, including $\delta^{7} \mathrm{Li}, \delta^{26} \mathrm{Mg}$ and ${ }^{234} \mathrm{U} /{ }^{238} \mathrm{U}$ isotopic ratios, and the cation, anion and trace element concentrations, can be found elsewhere (Pogge von Strandmann et al., 2006, 2008a,b).

\section{2. $\delta^{98 / 95}$ Mo and [Mo] analyses}

Between $100 \mathrm{ml}$ and $300 \mathrm{ml}$ of the filtered water sample was spiked with an appropriate amount of a ${ }^{100} \mathrm{Mo}-{ }^{97}$ Mo isotopic double spike and was evaporated to dryness. Bedload, colloidal and iron precipitate samples were dried, spiked with the ${ }^{100} \mathrm{Mo}-{ }^{97}$ Mo solution, and digested in a 3:1 $\mathrm{HF} / \mathrm{HNO}_{3}$ solution. The Mo in all sample types was subsequently separated and purified using anion exchange chromatography (Pearce et al., 2009). Isotopic measurements were made using a Nu-Instruments MC-ICP-MS at the Open University, with a long-term $\delta^{98 / 95}$ Mo reproducibility of $\pm 0.12 \%$ ( 2 standard deviation; Pearce et al., 2009).

\section{Results}

\subsection{Southeast Iceland}

Five water samples were analysed from rivers in the southeast region (Fig. 2). Three samples were taken from close to Vatnajökull glacier (E1, E3 and E5), one sample from further downstream (E7),

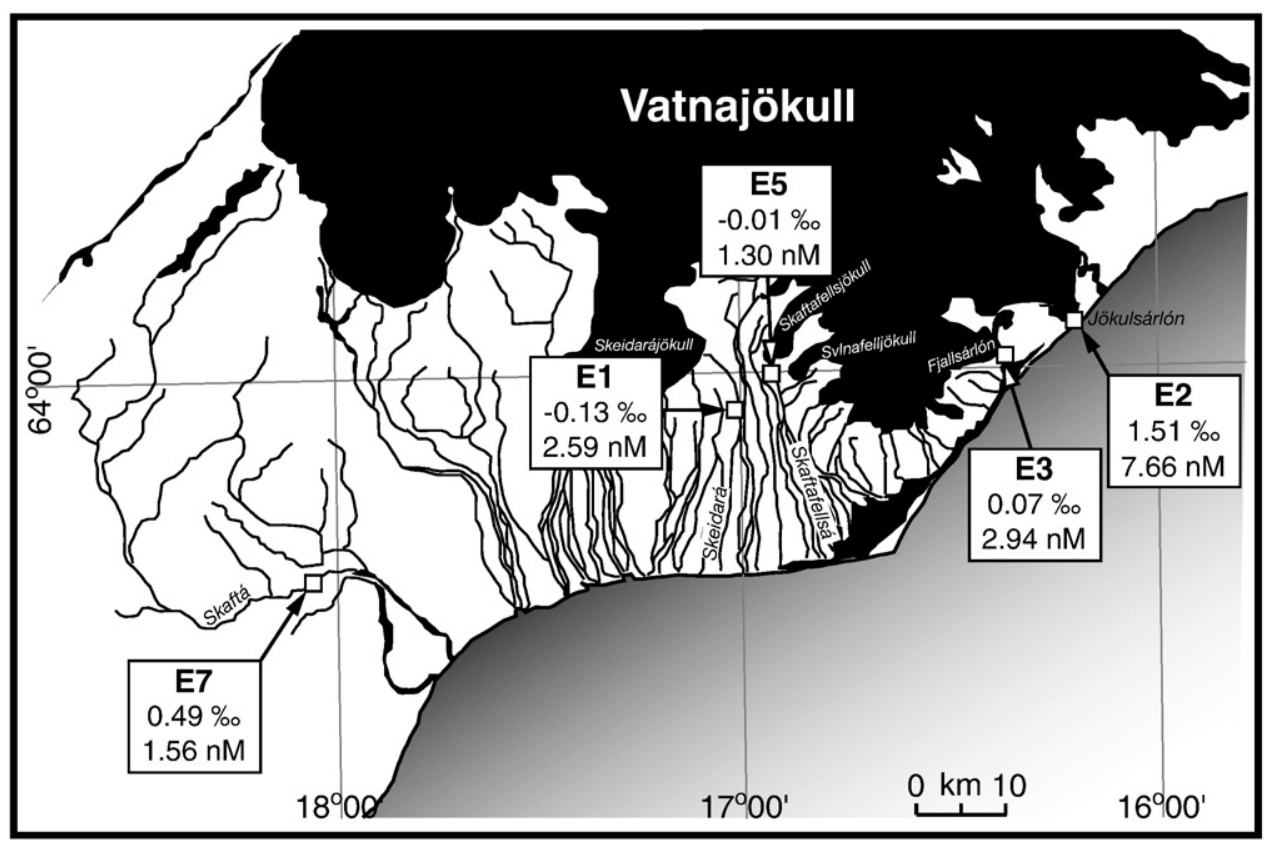

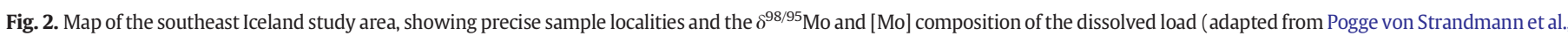

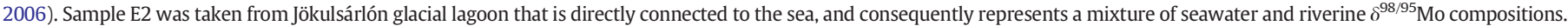




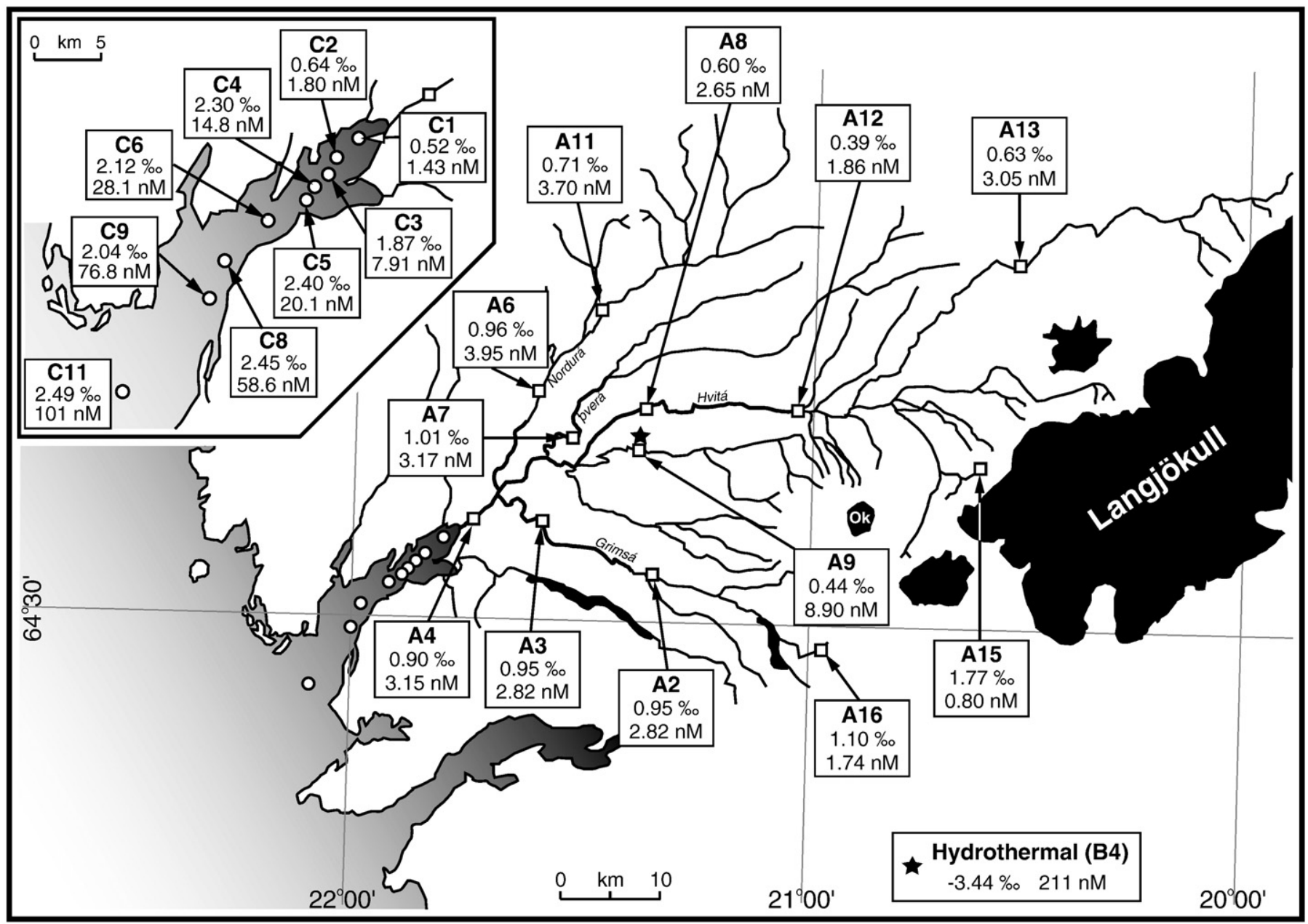

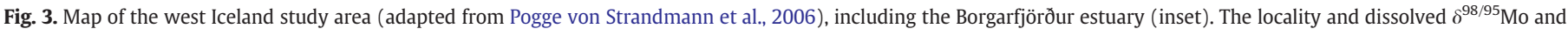

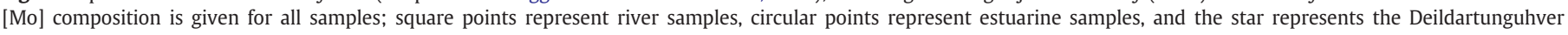
hydrothermal spring sampled close to the centre of the catchment area.

and one sample from a glacial lagoon (E2). The river samples from closest to the glacier have the lightest $\delta^{98 / 95}$ Mo isotope compositions that range from $-0.13 \%$ o to $0.07 \%$ ( Table 1 ). The concentration of Mo in these samples is relatively low, and varies from $1.30 \mathrm{nM}$ to $2.94 \mathrm{nM}$. Sample E7 has a similarly low [Mo] of $1.56 \mathrm{nM}$, but a heavier $\delta^{98 / 95} \mathrm{Mo}$ composition of $0.49 \%$. Finally, sample E2 taken from the glacial lagoon has significantly higher $\delta^{98 / 95} \mathrm{Mo}$ and [Mo] values of $1.51 \%$ and $7.66 \mathrm{nM}$ respectively. The $\delta^{98 / 95}$ Mo composition of the Fe-precipitated phase was determined for samples E2 and E3, and both yield a light isotope composition of $-0.65 \%$ and $-0.23 \%$ respectively. Analytical uncertainties for some samples are higher than expected from the long-term $\delta^{98 / 95}$ Mo reproducibility (ranging from $0.16 \%$ o to $0.40 \%$; Table 1 ), and predominantly reflect the low Mo content of the samples.

\subsection{West Iceland}

A total of 12 riverine samples were analysed from tributaries in the Borgarfjörður catchment area in the west of Iceland (Fig. 3). The bedload, colloid and Fe-precipitate fractions of the same samples were analysed where possible, and Deildartunguhver hydrothermal spring close to the centre of the studied area was also sampled. This hydrothermal spring is one of the largest in Iceland, and has the highest fluid discharge rates of any hydrothermal source in Europe of $\sim 200 \mathrm{l} / \mathrm{s}$, with fluids reaching the surface at $\sim 100^{\circ} \mathrm{C}$ (Kristmannsdóttir et al., 2005). Samples A15 and A16 taken from closest to the Langjökull glacier and have the heaviest riverine $\delta^{98 / 95}$ Mo values of $1.77 \%$ and $1.10 \%$ 。 respectively. They also have the lowest dissolved [Mo] of $0.80 \mathrm{nM}$ (A15) and $1.74 \mathrm{nM}$ (A16). Both $\delta^{98 / 95} \mathrm{Mo}$ and [Mo] display a general increase in samples taken downstream, with $\delta^{98 / 95}$ Mo ranging from $0.39 \%$ to $1.01 \%$ and [Mo] varying between $1.86 \mathrm{nM}$ and $3.95 \mathrm{nM}$ (Fig. 3; Table 1). The only exception to this is sample A9, which has a lighter $\delta^{98 / 95} \mathrm{Mo}$ composition than surrounding samples of $0.44 \%$, and a much higher [Mo] of $8.90 \mathrm{nM}$. This sample was taken close to the hydrothermal spring (sample B4), which has the lowest measured $\delta^{98 / 95}$ Mo composition of $-3.44 \%$ and the highest [Mo] of $211 \mathrm{nM}$. The $\delta^{98 / 95} \mathrm{Mo}$ composition of all four riverine phases was determined for sample A8; the dissolved load had a $\delta^{98 / 95}$ Mo value of $0.60 \%$, the bedload had a $\delta^{98 / 95}$ Mo composition of $-0.49 \%$, the Fe-precipitate fraction composition was $0.07 \%$. whilst the colloidal $\delta^{98 / 95}$ Mo value was $-0.31 \%$. Colloidal $\delta^{98 / 95} \mathrm{Mo}$ compositions were also determined for samples A4 (0.11\%) and A12 $(0.72 \%)$.

\subsection{Borgarfjörður estuary}

Samples from Borgarfjörður estuary show an initial abrupt increase in $\delta^{98 / 95} \mathrm{Mo}$, rising from $0.52 \%$ o to $2.30 \%$ over a distance of $\sim 3.5 \mathrm{~km}$ (Fig. 3; Table 2). This is followed by a more gradual increase in the rest of the estuary to a maximum $\delta^{98 / 95}$ Mo composition of $2.49 \%$ in the outermost sample (C11). Molybdenum abundances increase progressively from $1.43 \mathrm{nM}$ to $101 \mathrm{nM}$ throughout the estuary. The highest $\delta^{98 / 95} \mathrm{Mo}$ and [Mo] values measured in the Borgarfjörður Estuary are similar to those determined for the IAPSO 
Table 1

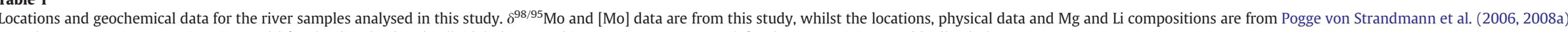
ample concentrations are given in nmol/l for the dissolved and colloidal phases and in $\mathrm{ng} / \mathrm{g}$ (or $\mathrm{mg} / \mathrm{g}$ or $\mu \mathrm{g} / \mathrm{g}$ ) for the Fe-precipitate and bedload phases.

\begin{tabular}{|c|c|c|c|c|c|c|c|c|c|c|c|c|c|c|c|c|}
\hline \multirow[t]{2}{*}{ Locality } & & \multirow{2}{*}{$\begin{array}{l}\text { Latitude } \\
\text { (North) }\end{array}$} & \multirow{2}{*}{$\begin{array}{l}\text { Longitude } \\
\text { (West) }\end{array}$} & \multirow{2}{*}{$\begin{array}{l}\text { Distance from source } \\
(\mathrm{km})\end{array}$} & \multirow[t]{2}{*}{$\mathrm{pH}$} & \multirow{2}{*}{$\begin{array}{l}\text { TDS } \\
(\mathrm{mg} / \mathrm{l})\end{array}$} & \multirow{2}{*}{$\begin{array}{l}\mathrm{TSS} \\
(\mathrm{mg} / \mathrm{l})\end{array}$} & \multirow{2}{*}{$\begin{array}{l}\text { Temp. } \\
\left({ }^{\circ} \mathrm{C}\right)\end{array}$} & \multirow{2}{*}{$\begin{array}{l}\text { Sample } \\
\text { Type }\end{array}$} & \multicolumn{2}{|c|}{$\delta^{98 / 95} \mathrm{Mo}$} & \multirow{2}{*}{$\begin{array}{l}\text { [Mo] } \\
(\mathrm{nmol} / \mathrm{l}) \text { or }(\mathrm{ng} / \mathrm{g})\end{array}$} & \multirow{2}{*}{$\begin{array}{l}\delta^{26} \mathrm{Mg} \\
(\%)\end{array}$} & \multirow{2}{*}{$\begin{array}{l}{[\mathrm{Mg}]} \\
(\mu \mathrm{mol} / \mathrm{l}) \text { or }(\mathrm{mg} / \mathrm{g})\end{array}$} & \multirow{2}{*}{$\begin{array}{l}\delta^{7} \mathrm{Li} \\
(\%)\end{array}$} & \multirow{2}{*}{$\begin{array}{l}{[\mathrm{Li}]} \\
(\mathrm{nmol} / \mathrm{l}) \text { or }(\mu \mathrm{g} / \mathrm{g})\end{array}$} \\
\hline & & & & & & & & & & $(\%)$ & 2 s.d. & & & & & \\
\hline \multirow[t]{7}{*}{ Southeast Iceland } & E1 & $63^{\circ} 58.585^{\prime}$ & $16^{\circ} 59.929^{\prime}$ & 7.51 & 9.11 & 22.1 & 1890 & 1.9 & Dissolved & -0.13 & 0.16 & 2.59 & 0.19 & 27.2 & 21.00 & 55.9 \\
\hline & E2 & $64^{\circ} 02.863^{\prime}$ & $16^{\circ} 10.909^{\prime}$ & 2.58 & 9.23 & 1479 & 203 & 2.1 & Dissolved & 1.51 & 0.22 & 7.66 & & 2360 & 34.10 & 1250 \\
\hline & & & & & & & & & Fe-ppt & -0.65 & 0.20 & 153 & & & & \\
\hline & E3 & $64^{\circ} 00.828^{\prime}$ & $16^{\circ} 22.567^{\prime}$ & 1.87 & 9.63 & 24.8 & 1380 & 3.1 & Dissolved & 0.07 & 0.21 & 2.94 & -0.28 & 16.6 & 26.50 & 9.20 \\
\hline & & & & & & & & & Fe-ppt & -0.23 & 0.07 & 631 & & & & \\
\hline & E5 & $64^{\circ} 00.459^{\prime}$ & $16^{\circ} 56.006^{\prime}$ & 2.31 & 9.69 & 18.4 & 2790 & 1.9 & Dissolved & -0.01 & 0.38 & 1.30 & 0.09 & 13.2 & 23.10 & 16.3 \\
\hline & E7 & $63^{\circ} 46.060^{\prime}$ & $18^{\circ} 07.725^{\prime}$ & 79.57 & 8.29 & 61.6 & 845 & 6.5 & Dissolved & 0.49 & 0.40 & 1.56 & -0.30 & 110 & 16.30 & 145 \\
\hline \multirow[t]{17}{*}{ West Iceland } & $\mathrm{A} 2$ & $64^{\circ} 32.407^{\prime}$ & $21^{\circ} 20.151^{\prime}$ & 22.82 & 8.08 & 32.3 & 569 & 13.5 & Dissolved & 0.95 & 0.14 & 2.82 & 0.14 & 64.6 & 25.40 & 21.9 \\
\hline & $\mathrm{A} 3$ & $64^{\circ} 35.576^{\prime}$ & $21^{\circ} 34.753^{\prime}$ & 35.54 & 8.07 & 40.4 & 522 & 12.4 & Dissolved & 0.95 & 0.17 & 2.82 & -0.63 & 98.4 & 34.50 & 15.6 \\
\hline & $\mathrm{A} 4$ & $64^{\circ} 36.199^{\prime}$ & $21^{\circ} 42.481^{\prime}$ & 65.12 & 7.93 & 34.7 & 612 & 9.0 & Dissolved & 0.90 & 0.14 & 3.15 & -0.23 & 76.2 & 21.10 & 41.8 \\
\hline & & & & & & & & & Colloid & 0.11 & 0.17 & 0.40 & & & & \\
\hline & A6 & $64^{\circ} 42.753^{\prime}$ & $21^{\circ} 36.361^{\prime}$ & 38.30 & 8.02 & 33.9 & 525 & 8.8 & Dissolved & 0.96 & 0.06 & 3.95 & 0.11 & 73.8 & 36.80 & 5.66 \\
\hline & A7 & $64^{\circ} 41.026^{\prime}$ & $21^{\circ} 31.475^{\prime}$ & 42.71 & 8.00 & 44.8 & 558 & 10.0 & Dissolved & 1.00 & 0.05 & 3.17 & -0.66 & 126 & 26.20 & 41.0 \\
\hline & A8 & $64^{\circ} 41.612^{\prime}$ & $21^{\circ} 24.867^{\prime}$ & 43.12 & 8.56 & 26.0 & 635 & 5.6 & Dissolved & 0.60 & 0.02 & 2.65 & 0.18 & 43.1 & 21.50 & 31.9 \\
\hline & & & & & & & & & Bedload & -0.49 & 0.08 & 532 & & 56.00 & 5.10 & 6.33 \\
\hline & & & & & & & & & Fe-ppt & 0.07 & 0.19 & 523 & & & & \\
\hline & & & & & & & & & Colloid & -0.31 & 0.20 & 0.16 & & & & \\
\hline & A9 & $64^{\circ} 38.925^{\prime}$ & $21^{\circ} 24.740^{\prime}$ & 27.17 & 8.11 & 58.0 & 679 & 13.8 & Dissolved & 0.44 & 0.06 & 8.90 & 0.29 & 150 & 18.70 & 43.5 \\
\hline & A11 & $64^{\circ} 45.940^{\prime}$ & $21^{\circ} 30.814^{\prime}$ & 24.72 & 7.95 & 33.1 & 362 & 12.5 & Dissolved & 0.71 & 0.05 & 3.70 & -0.48 & 74.7 & 28.20 & 7.76 \\
\hline & A12 & $64^{\circ} 42.359^{\prime}$ & $21^{\circ} 02.353^{\prime}$ & 27.20 & 9.30 & 25.9 & 675 & 6.4 & Dissolved & 0.39 & 0.02 & 1.86 & 0.64 & 34.0 & 18.50 & 37.5 \\
\hline & A13 & $64^{\circ} 48.101^{\prime}$ & $20^{\circ} 41.306^{\prime}$ & 21.00 & 8.44 & 60.5 & 406 & 12.9 & Dissolved & 0.63 & 0.00 & 3.05 & 0.10 & 66.8 & 23.70 & 75.6 \\
\hline & A15 & $64^{\circ} 38.791^{\prime}$ & $20^{\circ} 34.003^{\prime}$ & 0.30 & 6.46 & 0.7 & 559 & 1.5 & Dissolved & 1.77 & 0.28 & 0.80 & & 1.39 & & 1.54 \\
\hline & A16 & $64^{\circ} 28.733^{\prime}$ & $20^{\circ} 56.284^{\prime}$ & 3.02 & 9.54 & 23.1 & 364 & 6.6 & Dissolved & 1.10 & 0.07 & 1.74 & 0.15 & 33.0 & & 26.3 \\
\hline & B4 & $64^{\circ} 39.864^{\prime}$ & $21^{\circ} 24.740^{\prime}$ & 0.00 & 8.98 & 1600 & & 100 & Dissolved & -3.43 & 0.06 & 211 & 0.85 & 2410 & 10.90 & 5170 \\
\hline
\end{tabular}


Table 2

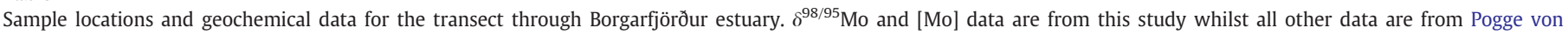
Strandmann et al. (2008b).

\begin{tabular}{|c|c|c|c|c|c|c|c|c|c|c|c|c|c|c|c|}
\hline \multirow[t]{2}{*}{ Locality } & & \multirow{2}{*}{$\begin{array}{l}\text { Latitude } \\
\text { (North) }\end{array}$} & \multirow{2}{*}{$\begin{array}{l}\text { Longitude } \\
\text { (West) }\end{array}$} & \multirow{2}{*}{$\begin{array}{l}\text { Distance from river mouth } \\
(\mathrm{km})\end{array}$} & \multirow{2}{*}{$\mathrm{pH}$} & \multirow{2}{*}{$\begin{array}{l}\text { TDS } \\
(\mathrm{mg} / \mathrm{l})\end{array}$} & \multirow{2}{*}{$\begin{array}{l}\text { Temp. } \\
\left({ }^{\circ} \mathrm{C}\right)\end{array}$} & \multirow{2}{*}{$\begin{array}{l}\mathrm{Cl}^{-} \\
(\mathrm{mmol} / \mathrm{l})\end{array}$} & \multicolumn{2}{|c|}{$\delta^{98 / 95} \mathrm{Mo}$} & \multirow{2}{*}{$\begin{array}{l}{[\mathrm{Mo}]} \\
(\mathrm{nmol} / \mathrm{l})\end{array}$} & \multirow{2}{*}{$\begin{array}{l}\delta^{26} \mathrm{Mg} \\
(\%)\end{array}$} & \multirow{2}{*}{$\begin{array}{l}{[\mathrm{Mg}]} \\
(\mathrm{mmol} / \mathrm{l})\end{array}$} & \multirow{2}{*}{$\begin{array}{l}\delta^{7} \mathrm{Li} \\
(\% \circ)\end{array}$} & \multirow{2}{*}{$\begin{array}{l}{[\mathrm{Li}]} \\
(\mu \mathrm{mol} / \mathrm{l})\end{array}$} \\
\hline & & & & & & & & & (\%) & 2 s.d. & & & & & \\
\hline \multirow{9}{*}{$\begin{array}{l}\text { Borgarfjörður } \\
\text { estuary }\end{array}$} & $\mathrm{C} 1$ & $64^{\circ} 34.290^{\prime}$ & $21^{\circ} 49.299^{\prime}$ & 6.00 & 7.92 & 33.4 & 7.7 & 0.410 & 0.52 & 0.02 & 1.43 & -0.28 & 0.083 & 18.30 & 0.038 \\
\hline & $\mathrm{C} 2$ & $64^{\circ} 33.584^{\prime}$ & $21^{\circ} 51.107^{\prime}$ & 7.75 & 7.95 & 47.2 & 8.2 & 0.855 & 0.64 & 0.26 & 1.80 & -0.55 & 0.110 & 23.14 & 0.057 \\
\hline & C3 & $64^{\circ} 33.207^{\prime}$ & $21^{\circ} 51.792^{\prime}$ & 8.70 & 7.94 & 1419 & 9.4 & 18.4 & 1.87 & 0.12 & 7.91 & -0.68 & 2.76 & 31.65 & 1.36 \\
\hline & $\mathrm{C} 4$ & $64^{\circ} 32.924^{\prime}$ & $21^{\circ} 52.529^{\prime}$ & 9.50 & 8.08 & 3570 & 9.5 & 51.0 & 2.30 & 0.14 & 14.8 & -0.69 & 5.72 & 31.84 & 3.03 \\
\hline & $\mathrm{C} 5$ & $64^{\circ} 32.623^{\prime}$ & $21^{\circ} 53.270^{\prime}$ & 10.20 & 8.16 & 4900 & 9.9 & 115 & 2.40 & 0.05 & 20.1 & -0.65 & 8.46 & 32.10 & 4.37 \\
\hline & C6 & $64^{\circ} 31.686^{\prime}$ & $21^{\circ} 56.450^{\prime}$ & 13.30 & 8.22 & 6460 & 10.2 & 151 & 2.12 & 0.05 & 28.1 & -0.73 & 13.4 & 32.32 & 6.92 \\
\hline & C8 & $64^{\circ} 30.035^{\prime}$ & $21^{\circ} 59.427^{\prime}$ & 17.00 & 8.27 & 10,930 & 11.0 & 275 & 2.45 & 0.04 & 58.6 & -0.69 & 23.8 & 31.88 & 13.0 \\
\hline & C9 & $64^{\circ} 29.019^{\prime}$ & $22^{\circ} 01.071^{\prime}$ & 19.20 & 8.28 & 15,400 & 11.3 & 385 & 2.04 & 0.12 & 76.8 & -0.7 & 33.2 & 31.50 & 17.5 \\
\hline & C11 & $64^{\circ} 26.050^{\prime}$ & $22^{\circ} 08.966^{\prime}$ & 28.00 & 8.29 & 23,500 & 12.4 & 542 & 2.49 & 0.01 & 101 & -0.82 & 48.7 & 31.65 & 23.5 \\
\hline
\end{tabular}

seawater salinity standard (2.41\%。 and 120 nM; Pearce et al., 2009), suggesting that an open ocean Mo-isotope signal was attained.

\section{Discussion}

\subsection{Sources of dissolved riverine Mo}

River sources vary in Iceland as a function of the age of the underlying bedrock, with spring-fed rivers dominating the younger regions and surface runoff rivers being more prevalent in olderterrains (Gislason et al., 1996). In addition several rivers are completely dominated by glacial discharge. These differences in river type are reflected in the chemical composition of the dissolved load, as well as the TDS, TSS and other physical characteristics
(Gislason et al., 2009; Pogge von Strandmann et al., 2006, 2008a). The different sources of dissolved Mo in the rivers analysed in this study are reflected in the $\delta^{98 / 95}$ Mo values (Fig. 4), and suggest three main Mo-inputs; glacial ice, dissolution of the basaltic bedrock, and hydrothermal Mo. Contamination from Mo in seawater is also apparent in sample E2, which was collected from Jökulsárlón, a glacial lagoon (Fig. 2).

\subsubsection{Glacial ice}

The $\delta^{98 / 95}$ Mo composition of glacial ice has not been measured directly due to the extremely low concentration of Mo. Nevertheless, $\delta^{98 / 95} \mathrm{Mo}_{\text {ice }}$ can be inferred from sample A15 that was taken $300 \mathrm{~m}$ from the edge of Langjökull glacier at the top of Hvítá River (Fig. 3; Pogge von Strandmann et al., 2006). The dominance of glacial

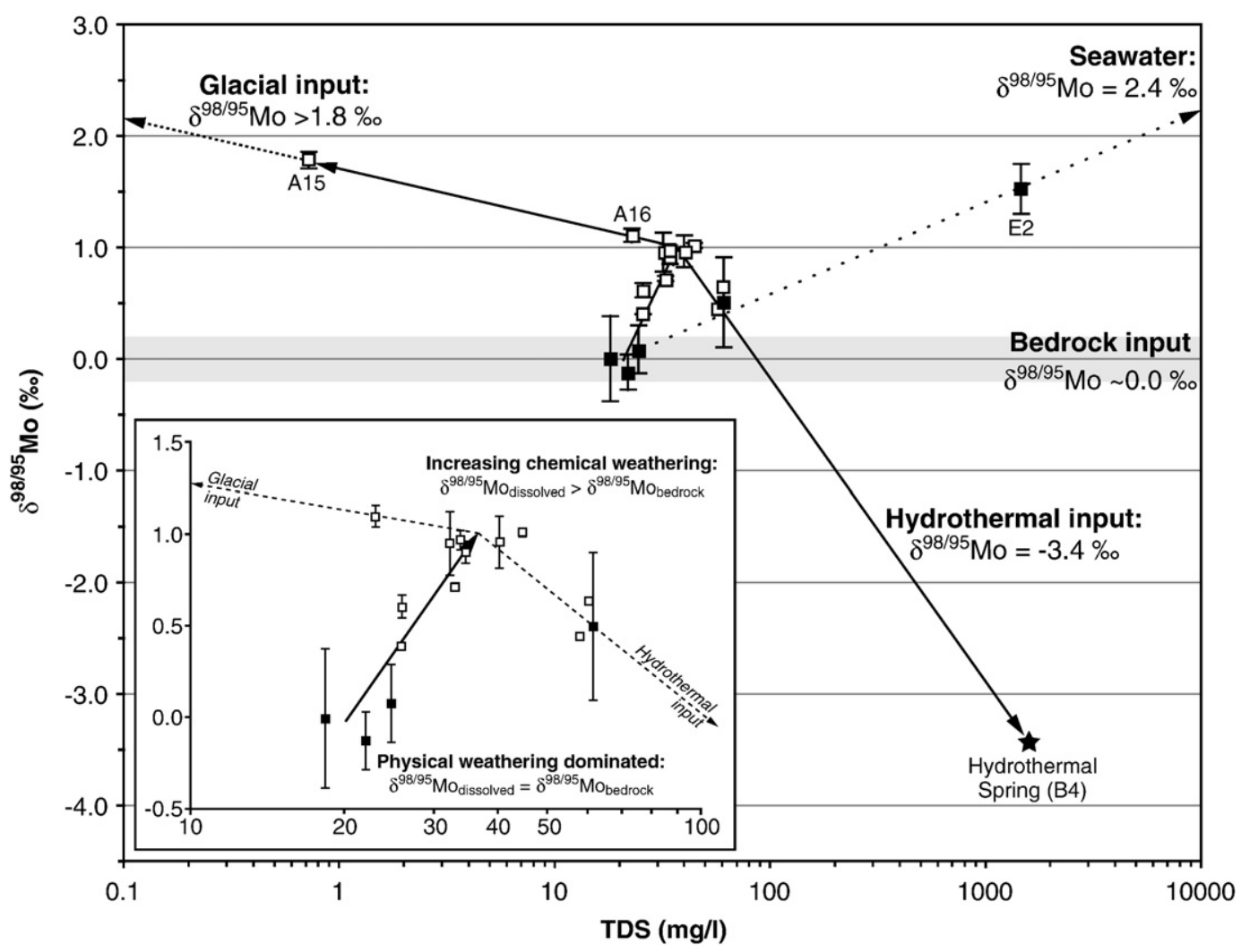

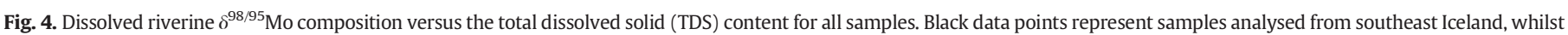

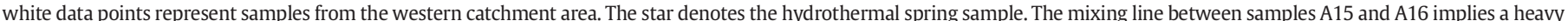

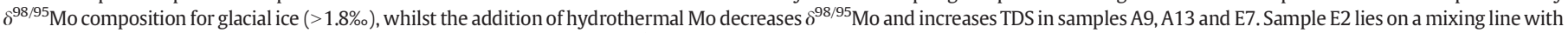

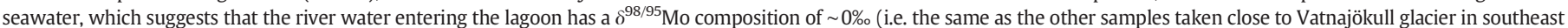

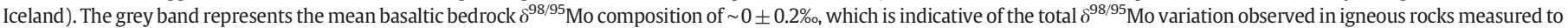

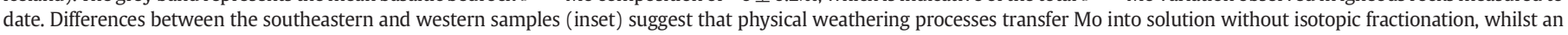
increasing degree of chemical weathering during Mo transportation preferentially removes light Mo-isotopes, leaving the residual dissolved load isotopically heavy. 
discharge in this sample is reflected by its low pH (6.46), temperature $\left(1.5^{\circ} \mathrm{C}\right)$ and TDS content $(0.73 \mathrm{mg} / \mathrm{l})$. In addition, the $\delta^{7} \mathrm{Li}$ and ${ }^{234} \mathrm{U} /{ }^{238} \mathrm{U}$ isotopic ratios of this sample are very similar to those measured in the actual glacial ice (Pogge von Strandmann et al., 2006). The $\delta^{98 / 95} \mathrm{Mo}$ composition of sample A15 (1.77\%o) is the heaviest riverine value measured in this study, suggesting that glacial ice has an isotopically heavy Mo composition. This is supported by the $\delta^{98 / 95}$ Mo composition of sample A16 (1.10\%), which comes from slightly further away from the edge of Langjökull (at the top of Grimsá river; Fig. 3), and also has a heavy $\delta^{98 / 95}$ Mo value. Comparison of $\delta^{98 / 95} \mathrm{Mo}$ with the TDS content of both samples (Fig. 4) suggests that pure glacial ice has a $\delta^{98 / 95} \mathrm{Mo}$ composition $>1.8 \%$. The heavy $\delta^{98 / 95} \mathrm{Mo}_{\text {ice }}$ composition is most likely derived from seawater $\left(\delta^{98 / 95} \mathrm{Mo}_{\text {seawater }}=2.4 \%\right.$; Barling et al., 2001; Siebert et al., 2003; Pearce et al., 2009), as this is ultimately the source of the water within the glacier (via rain and snowfall), and there is no evidence for significant anthropogenic pollution in this part of Iceland (Caritat et al., 2005). The preservation of such heavy $\delta^{98 / 95}$ Mo values in glacial ice also suggests that Mo-isotopes are not significantly fractionated during the evaporation-precipitation process, or repeated freeze-thaw processes within the glacier. This behaviour is similar to that seen for other stable isotope systems, such as Li (Pogge von Strandmann et al., 2006), Mg (Pogge von Strandmann et al., 2008a) and $\mathrm{Si}$ (Georg et al., 2007). The heavy $\delta^{98 / 95} \mathrm{Mo}_{\text {ice }}$ composition suggests that precipitation may also directly supply isotopically heavy Mo to the river system, although the very low concentrations of Mo expected within rainwater suggest that it is unlikely to have a significant effect on riverine $\delta^{98 / 95}$ Mo compositions.

\subsubsection{Underlying bedrock}

Unlike samples A15 and A16 from close to Langjökull glacier in western Iceland, those taken from the vicinity of Vatnajökull glacier in the southeast of Iceland (samples E1, E3 and E5) have $\delta^{98 / 95}$ Mo values of $\sim 0 \%$ (Figs. 2 and 4 ). Whilst these samples also have low temperatures and TDS contents, their TSS content is much higher, ranging from $1890 \mathrm{mg} / \mathrm{l}$ to $2790 \mathrm{mg} / \mathrm{l}$ (in comparison to values of $559 \mathrm{mg} / \mathrm{l}$ and $364 \mathrm{mg} / \mathrm{l}$ for samples A15 and A16 respectively). The higher content of suspended material in the southeastern glacial rivers implies they are dominated by physical weathering processes associated with active flaciation, both beneath and adjacent to the Vatnajökull glacier (Pogge von Strandmann et al., 2006). In addition, high $\mathrm{pH}$ values in the sub-glacial fluids (resulting from the isolation from atmospheric $\mathrm{CO}_{2}$ ) promote the dissolution of Al-silicates such as basaltic glass and feldspars (Gislason and Oelkers, 2003; WolffBoenisch et al., 2006). Molybdenum concentrations in Icelandic basalts are relatively high (typically higher than the $\sim 1 \mathrm{ppm}$ continental average; Arnórsson and Óskarsson, 2007). As a result the dissolved Mo content of these rivers is likely to be dominated by the dissolution of the underlying bedrock. The fact that the $\delta^{98 / 95} \mathrm{Mo}$ composition of samples E1, E3 and E5 is the same as that of the underlying bedrock (i.e. 0\%; Siebert et al., 2003; Pearce et al., 2009) implies that the direct transfer of Mo from bedrock to solution during basalt weathering occurs with little accompanying isotope fractionation. This is consistent with leaching experiments on granite, which show that the Mo released is isotopically indistinguishable from the source rock (Siebert et al., 2003).

\subsubsection{Hydrothermal Mo}

The third isotopically distinct Mo source identified in the Icelandic rivers is hydrothermal fluids. Water taken from Deildartunguhver hydrothermal spring in the Borgarfjörður catchment (sample B4; Fig. 3) has an extremely light $\delta^{98 / 95}$ Mo composition of $-3.44 \%$ and a high dissolved Mo concentration of $211 \mathrm{nM}$. This is the first reported Mo-isotope value for a terrestrial hydrothermal spring, and is the lightest $\delta^{98 / 95}$ Mo value of any sample type measured to date. Lowtemperature hydrothermal $\delta^{98 / 95}$ Mo data have previously been reported by McManus et al. (2002) from the Baby Bare ridge flank system in the Pacific Ocean ( $\sim 100 \mathrm{~km}$ east of the Juan de Fuca Ridge), where the hydrothermal fluids were found to have a mean $\delta^{98 / 95} \mathrm{Mo}$ composition of $0.8 \%$. However, it is difficult to ascertain the extent to which these marine samples were influenced by the isotopically heavy $\delta^{98 / 95}$ Mo composition of seawater.

As only one hydrothermal site has been sampled in this study, verification of isotopically light $\delta^{98 / 95} \mathrm{Mo}_{\text {hydrothermal }}$ compositions in other settings is undoubtedly needed. Nevertheless, the observation of this extremely light $\delta^{98 / 95}$ Mo isotope composition warrants a preliminary speculation as to its origin. A strongly negative fractionation between oxidised molybdate species $\left(\mathrm{MoO}_{4}^{2-}\right)$ and reduced sulphidic Mo species $\left(\mathrm{MoS}_{4}^{2-}\right)$ is predicted from quantum calculations, with an inferred $\Delta^{98 / 95} \mathrm{Mo}_{\text {oxic-sulphidic }}$ fractionation of $\sim-5.3 \%$ o (Tossell, 2005). This difference is not observed in strongly reducing environments at the Earth's surface (for example in euxinic marine basins such as the Black Sea; Neubert et al., 2008a) because the high equilibrium constant of the reaction under such conditions ensures that it is stoichiometrically complete (Tossell, 2005). In open hydrothermal systems, however, it is possible that interactions between $\mathrm{H}_{2} \mathrm{~S}$-rich fluids and oxic Mo species present in the country rock will result in the non-stoichiometric formation of isotopically light $\mathrm{MoS}_{4}^{2-}$ species within the fluid phase. In such systems, equilibrium between the various Mo-phases is not necessarily attained and may result in large, hitherto unobserved, fractionation effects. The absence of such light $\delta^{98 / 95}$ Mo compositions in the hydrothermal molybdenite deposits analysed to date (e.g. Barling et al., 2001; Wieser and de Laeter, 2003; Hannah et al., 2007; Malinovsky et al., 2007) may reflect isotopic re-equilibration of the dissolved Mo species before or during precipitation, or a shift to heavier $\delta^{98 / 95} \mathrm{Mo}$ compositions within the source fluid as a consequence of Rayleigh fractionation effects (Hannah et al., 2007).

The influence that the very light $\delta{ }^{98 / 95} \mathrm{Mo}_{\text {hydrothermal value has on }}$ the composition of the dissolved Mo load in the Icelandic rivers can be seen in three of the analysed samples. Samples A9, A13 and E7 have similar $\delta^{98 / 95}$ Mo compositions of $\sim 0.5 \%$ (Fig. 4), which are lighter than the values of samples measured at similar points on the rivers course (Fig. 3). These samples also have higher [Mo], $\mathrm{SO}_{4}^{2-}$ concentrations and TDS contents, and slightly higher temperatures (Table 1) that are suggestive of an, at least, partial hydrothermal Mo component in the dissolved load (Pogge von Strandmann et al., 2006). Hydrothermal contamination is certainly expected in sample A9, which was taken from close to the Deildartunguhver hydrothermal spring (Fig. 3). Similarly, sample E7 comes from a river that occasionally drains subglacial geothermal lakes under the western Vatnajökull glacier (Johannesson et al., 2007).

\subsection{Mo-isotope fractionation during weathering and riverine transportation}

Although the three main Mo sources have isotopically distinct compositions, $\delta^{98 / 95}$ Mo values in most of the analysed Icelandic rivers cannot be attributed to the simple mixing of these inputs. Measured riverine $\delta^{98 / 95}$ Mo compositions vary from $-0.13 \%$ 。 to $1.01 \%$ (if the effects of glacial ice and seawater are discounted), and the observation that these values are predominantly heavy implies that most Mo in the dissolved phase is not hydrothermally sourced. Inferred concentrations of Mo in glacial ice are too low to significantly impact riverine $\delta^{98 / 95} \mathrm{Mo}$ compositions away from the glacial edge, and are therefore unlikely to be the cause for the observed positive values. Lithological variations are known to affect the Mo-isotope composition of the dissolved phase over geographically short distances (e.g. Archer and Vance, 2008; Neubert et al., 2008b). However, such effects cannot account for the $>1 \%$ o variation recorded in this study, because the $\delta^{98 / 95}$ Mo composition of the predominantly basaltic bedrock in Iceland is $\sim 0 \%$, and is unlikely to vary by more than $0.5 \%$ (the total range observed in all igneous rocks; Anbar, 2004; Siebert et al., 2003; Pearce et al., 2009). Consequently the 
shift to heavier $\delta^{98 / 95}$ Mo values within the dissolved load of these Icelandic rivers must reflect fractionation processes occurring during the weathering and transport of Mo.

If it is assumed that most Mo in the dissolved phase is derived from the underlying bedrock (e.g. Arnórsson and Óskarsson, 2007), then only samples E1, E3 and E5 from southeast Iceland display the expected basaltic $\delta^{98 / 95}$ Mo composition of $\sim 0 \%$. These samples were taken from close to Vatnajökull glacier, in a region where high rates of physical erosion and sub-glacial dissolution of basaltic glass enable Mo to be directly transferred from bedrock to solution without significant fractionation (Section 5.1.2). In contrast, riverine $\delta{ }^{98 / 95}$ Mo compositions from western Iceland vary from $0.39 \%$ o to $1.01 \%$ (excluding samples A15 and A16 that have significant glacial-ice contributions), and generally increase with distance from the source (such that lighter $\delta^{98 / 95}$ Mo values are found upstream and heavier $\delta^{98 / 95}$ Mo values occur downstream; Fig. 3). This is particularly clear when samples taken from different points on the same river or tributary are compared. For example; the Nordurá tributary increases from $0.71 \%$ (A11) to $0.96 \%$ 。 (A6), whilst Hvitá River progressively rises from $0.39 \%$ (A12) to $0.60 \%$ (A8) to $0.90 \%$ (A4). Given that the $\delta^{98 / 95}$ Mo composition of the basaltic bedrock is unlikely to change significantly within this area, this increase in $\delta^{98 / 95}$ Mo is likely to reflect the progressive removal of isotopically light Mo along the river profile.

The preferential removal of light Mo-isotopes from the dissolved phase during weathering and riverine transportation has been observed in other river systems (Archer and Vance, 2008), and two possible fractionation mechanisms have been proposed to account for this process: (1) Removal of isotopically light Mo from river water via adsorption to the particulate load during transportation; (2) Fractionation during weathering, with the retention of light Mo-phases in soils and on secondary clay minerals or Fe-Mn oxides, or colloids. To assess which of these processes is likely to be responsible for the fractionation in the Icelandic rivers, the particulate Mo fraction (colloidal, Fe-precipitate and bedload) for a selection of samples was analysed (Fig. 5; Table 1). The particulate phases were found to be isotopically lighter than the dissolved load, and consequently act as a sink for isotopically light Mo. Interestingly, however, the $\delta^{98 / 95} \mathrm{Mo}$

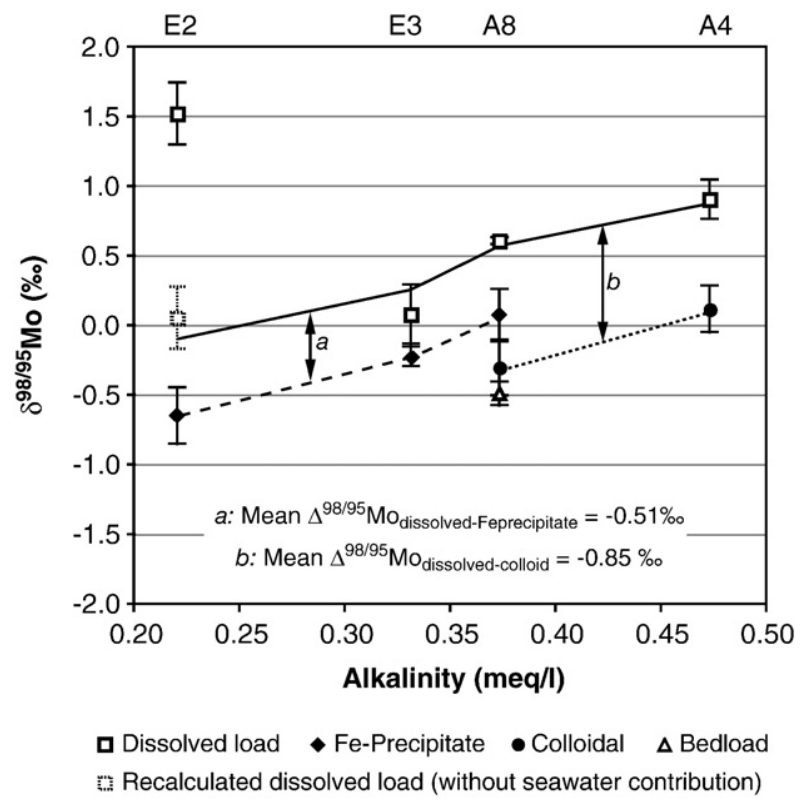

Fig. 5. Comparison between dissolved and particulate $\delta^{98 / 95}$ Mo compositions and alkalinity. Higher alkalinity indicates more contact with atmospheric $\mathrm{CO}_{2}$, and implies more silicate weathering. The effect of seawater contamination in sample E2 is accounted for using $\left[\mathrm{Cl}^{-}\right]$ (Pogge von Strandmann et al., 2006). The particulate phases have isotopically lighter compositions than dissolved Mo, and imply an average $\Delta^{98 / 95} \mathrm{Mo}_{\text {dissolved-Feprecipitate }}$ of $-0.51 \%$ 。 and an average $\Delta^{98 / 95} \mathrm{Mo}_{\text {dissolved-colloid }}$ fractionation of $-0.85 \%$. composition of the particulate phases also appears to follow the composition of the dissolved Mo (Fig. 4). As a result the net offset between the dissolved load and the particulate phase remains constant within the river course; $\Delta^{98 / 95} \mathrm{Mo}_{\text {dissolved-Feprecipitate }}$ in the analysed Icelandic rivers is $-0.51 \%$, whilst $\Delta^{98 / 95} \mathrm{Mo}_{\text {dissolved-colloid }}$ is $-0.85 \%$ o (although this represents the minimum extent of fractionation, as the colloidal fraction was not removed from the dissolved load prior to analysis). This, combined with the low concentration of Mo within the riverine particulate fraction (e.g. Kawakubo et al., 2002; Archer and Vance, 2008), suggests that the adsorption of isotopically light Mo to particulate phases within the river itself cannot be driving the dissolved load to heavier $\delta^{98 / 95}$ Mo compositions. Consequently the progressive increase in riverine $\delta^{98 / 95}$ Mo values in the western catchment is thought to be caused by the addition of isotopically heavy groundwater that has passed through regolith profiles, within which isotopically light Mo is removed via adsorption and/or incorporation to secondary phases. This is consistent with preliminary Mo-isotope results from soil profiles (Pett-Ridge et al., 2008), and suggests that the dissolved load in the studied catchment may not become isotopically heavier than $\sim 1 \%$ o due to the limited development of soil and vegetation in the upper reaches of the catchment. Regardless of the fractionation mechanism, these results demonstrate that the dissolved load, colloids and suspended particulates remain coupled throughout the Mo transport process, as observed for uranium-series isotopes elsewhere (Porcelli et al., 1997; Andersson et al., 1998).

\subsection{Borgarfjörður estuary $\delta^{98 / 95}$ Mo profile}

Molybdenum behaves conservatively in the oceans, with a uniform concentration of $\sim 120 \mathrm{nM}$ and $\delta^{98 / 95}$ Mo composition of $\sim 2.4 \%$ 。 (Barling et al., 2001; Siebert et al., 2003; Anbar, 2004; Pearce et al., 2009). The relatively high abundance of Mo in present-day seawater reflects the stability of the dissolved $\mathrm{MoO}_{4}^{2-}$ species under oxidising conditions (Savenko, 1996), and results in a long oceanic residence time of $780 \mathrm{kyr}$ (Manheim and Landergren, 1974; Colodner et al., 1995; Morford and Emerson, 1999). Because aqueous $\mathrm{MoO}_{4}^{2-}$ is chemically inert, river water and seawater are expected to exhibit a simple mixing behaviour between $\delta^{98 / 95} \mathrm{Mo}$ and [Mo] in the estuarine environment. Such a relationship is observed in most of the samples taken from the Borgarfjörður estuary (Fig. 6a), and has also been seen in the Itchen estuary of SE England (Archer and Vance, 2008). Samples C6 and C9 in the Borgarfjörður estuary have $\delta^{98 / 95}$ Mo compositions slightly below the expected mixing trend, which are likely to reflect the input of isotopically lighter riverine Mo from nearby tributaries (Fig. 3).

Surprisingly, estuary samples taken from closest to the river mouth ( $\mathrm{C} 1$ and $\mathrm{C} 2$ ) have $\delta^{98 / 95} \mathrm{Mo}$ and [Mo] values markedly below that of the incoming river water (as reflected by sample A4; $0.90 \%$, $3.15 \mathrm{nM}$ ). It is possible that this deviation from the expected mixing behaviour reflects natural variations in the water shed under different metrological and/or tidal conditions. However, a decrease in $\delta^{98 / 95} \mathrm{Mo}$ in the low salinity mixing zone is also consistent with the release of light Mo-isotopes adsorbed to the particulate phases: colloidal Mo is $0.79 \%$ o lighter than the dissolved Mo close to the river mouth (Fig. 5), and the release of this isotopically light fraction due to the change in salinity in the estuary may result in the observed $0.38 \%$ decrease in $\delta^{98 / 95} \mathrm{Mo}$. Desorption of light Mo from the particulate phase is also consistent with a non-conservative behaviour of $U$ and a decrease in $\delta^{7} \mathrm{Li}$ observed in the same samples (Fig. 6b; Pogge von Strandmann et al., 2008b). The desorption of isotopically light Mo from the particulate phases does not concur, however, with the decrease in [Mo] observed in the low salinity zone. The non-conservative behaviour of Mo in this manner has been recorded in other coastal regions (e.g. Dellwig et al., 2007), and may relate to Mo-scavenging by of organic-matter and/or changes in redox conditions within the estuarine sediments. This suggests that whilst Mo 
A

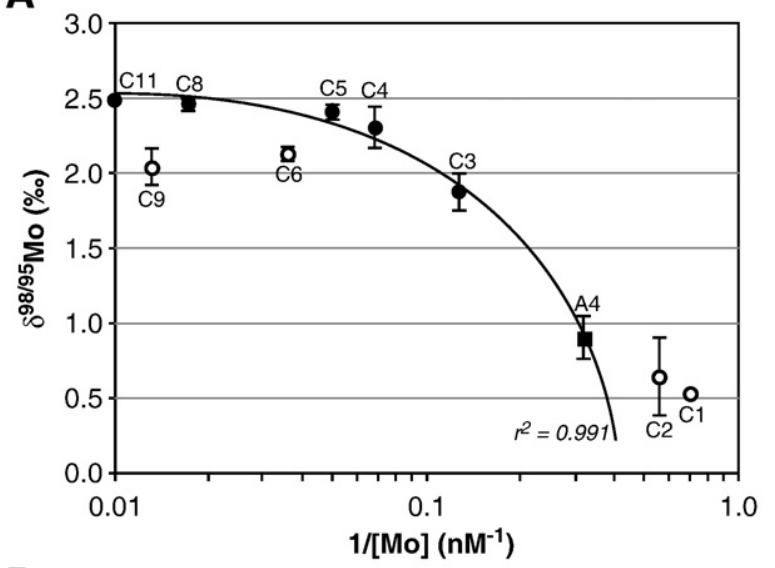

B

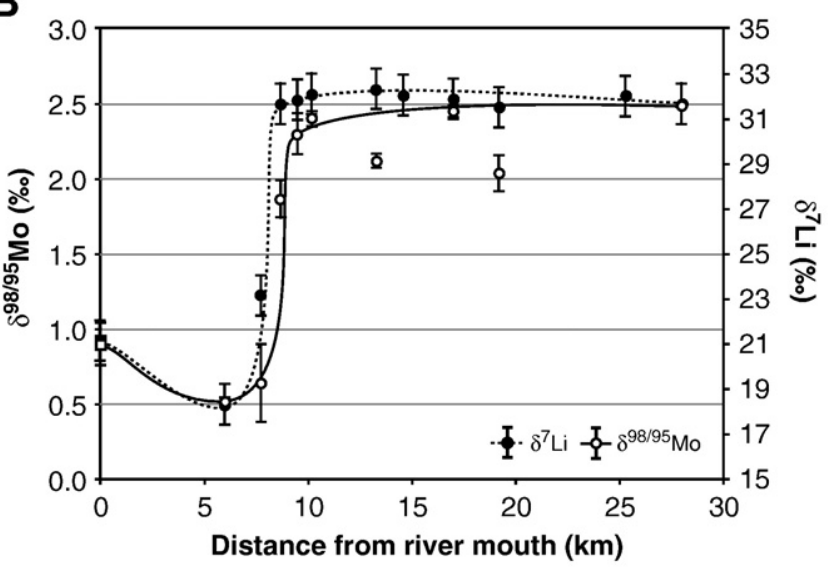

Fig. 6. $\delta^{98 / 95} \mathrm{Mo}$ versus [Mo] (A), and changes in $\delta^{98 / 95} \mathrm{Mo}$ and $\delta^{7} \mathrm{Li}$ with distance from the river mouth (B) for Borgarfjörður estuary, west Iceland. The Mo data is from this study, whilst $\delta^{7} \mathrm{Li}$ is from Pogge von Strandmann et al. (2008b). Black data points in (A) define a conservative mixing behaviour between the riverine and seawater end members, whilst the samples shown in white lie off this trend (see text for details). Note that the river mouth composition in (B) is defined as that of sample A4, although in reality this sample was taken from slightly further upstream, away from tidal influences (Fig. 3). A reduction in the dissolved isotopic composition of both Mo and $\mathrm{Li}$ occurs in the low salinity mixing zone (B), which suggests that isotopically light Mo and Li phases adsorbed to colloidal and particulate fractions in the river water may be released upon a change in salinity.

exhibits a predominantly simple mixing relationship in estuarine environments, non-conservative behaviour may occur in the low salinity zone of, at least, some estuaries.

\subsection{Implications for oceanic Mo-isotope budgets}

The input of isotopically heavy dissolved Mo into the oceans, demonstrated in this study and other studies of rivers (Archer and
Vance, 2008; Neubert et al., 2008b), is at odds with the value inferred from the mean $\delta^{98 / 95}$ Mo composition of continental rocks of $\sim 0 \%$ 。 (Barling et al., 2001; Siebert et al., 2003). This has important consequences for the use of the $\delta^{98 / 95}$ Mo system to model the extent of marine anoxia in the geological record, as discussed by Archer and Vance (2008). An isotopically heavy $\delta^{98 / 95} \mathrm{Mo}_{\text {input }}$ composition assumes, however, that all Mo entering the oceans from rivers is in the dissolved phase; it does not take into account the potential release of isotopically light Mo from particulate phases, or the continued dissolution of the continental material within the estuaries and/or oceans. Comparison of the dissolved, colloidal and suspended phases in sample A8 (near the centre of Hvitá River) demonstrates that in this instance the true dissolved load only accounts for $\sim 40 \%$ of Mo reaching the oceans, and that most Mo resides in the suspended fraction with only a small proportion $(<3 \%)$ being associated with the colloids (Table 3 ).

The small proportion of Mo in the colloidal phase means that, even though it is isotopically lighter than the dissolved load, the complete release of Mo from this phase is unlikely to significantly affect oceanic $\delta^{98 / 95}$ Mo. In contrast, given that high-relief and tectonically active volcanic islands such as Iceland contribute over $45 \%$ of suspended material to the oceans (Milliman and Syvitski, 1992; Gaillardet et al., 1999), and that up to $0.05 \%$ of the Icelandic suspended material dissolves in seawater each day (Stefansdottir and Gislason, 2005; Gislason et al., 2006), the release of Mo from the suspended load may have a significant impact on $\delta^{98 / 95} \mathrm{Mo}_{\text {seawater }}$. This is supported by the experimentally determined dissolution rates of basalt in seawater (Gislason and Oelkers, 2003; Oelkers et al., 2009), and evidence for Li isotopic variations in the suspended material of Borgarfjörður estuary (Pogge von Strandmann et al., 2008b). Assuming that the mean annual discharge of Hvitá River is $2.52 \mathrm{~km}^{3}$ (Gannoun et al., 2006), then $\sim 15,600 \mathrm{~mol} / \mathrm{yr}$ of Mo is transported to the oceans from this catchment area in the west of Iceland (Table 3). Of this, $6280 \mathrm{~mol} / \mathrm{yr}$ is transported directly in the dissolved load (equivalent to $0.003 \%$ of the inferred global riverine Mo flux of $1.8 \times 10^{8} \mathrm{~mol} / \mathrm{yr}$; McManus et al., 2006), and has an inferred isotopically heavy $\delta^{98 / 95}$ Mo composition of $0.66 \%$. If, however, most Mo from the colloidal and suspended load fractions in this river was released upon reaching the ocean, then the net $\delta^{98 / 95} \mathrm{Mo}_{\text {input }}$ composition would fall to $-0.02 \%$, i.e. equivalent to the composition of the weathered bedrock within this catchment. Whilst the release of Mo from the weathering of the suspended load in the oceans will probably not to go to completion, these calculations demonstrate that the true isotopic composition of Mo entering the oceans is likely to be below that inferred from the dissolved load alone, and should be taken into consideration in future Mo-isotope studies.

\section{Conclusions}

River samples in southeast and west Iceland display dissolved $\delta^{98 /}$ ${ }^{95}$ Mo compositions that vary from $-0.13 \%$ 。 to $1.77 \%$. These

Table 3

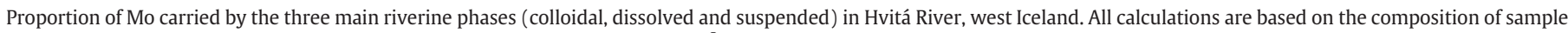
$\mathrm{A} 8$, and fluxes have been determined using an annual discharge rate of $2.52 \mathrm{~km}^{3} / \mathrm{yr}$ (Gannoun et al., 2006).

\begin{tabular}{|c|c|c|c|c|c|}
\hline \multirow[t]{2}{*}{ Riverine Mo phase } & \multirow[t]{2}{*}{ Measured [Mo] } & \multirow{2}{*}{$\begin{array}{l}\text { Mo flux from } \\
\text { Hvitá River }\end{array}$} & \multirow{2}{*}{$\begin{array}{l}\text { Relative proportion of Mo } \\
\text { transported to the ocean }\end{array}$} & \multicolumn{2}{|c|}{$\delta^{98 / 95} \mathrm{Mo}$} \\
\hline & & & & (\%) & 2 s.d. \\
\hline Colloidal & $0.16 \mathrm{nmol} / \mathrm{l}$ & $402 \mathrm{~mol} / \mathrm{yr}$ & $2.6 \%$ & -0.31 & 0.20 \\
\hline Dissolved $^{\mathrm{a}}$ & $2.49 \mathrm{nmol} / \mathrm{l}$ & $6280 \mathrm{~mol} / \mathrm{yr}$ & $40.4 \%$ & 0.66 & 0.02 \\
\hline Suspended $^{\mathrm{b}}$ & $3.52 \mathrm{nmol} / 1$ & $8870 \mathrm{~mol} / \mathrm{yr}$ & $57.0 \%$ & -0.49 & 0.08 \\
\hline Fe-precipitate & $523 \mathrm{ng} / \mathrm{g}$ & - & - & 0.07 & 0.19 \\
\hline Bedload & $531 \mathrm{ng} / \mathrm{g}$ & - & - & -0.49 & 0.08 \\
\hline \multicolumn{2}{|c|}{ Net discharge of Mo per year from Hvitá River: } & $15,600 \mathrm{~mol} / \mathrm{yr}$ & & & \\
\hline \multicolumn{2}{|c|}{ Proportion of global Mo accounted for by Hvitá River: } & $0.009 \%$ & & & \\
\hline
\end{tabular}

a 'True' dissolved load, as calculated without the colloidal component.

b Suspended load Mo content and isotopic composition are defined as that of the bedload relative to the TSS content of the sample (635 mg/l). 
differences can be attributed to both variations in Mo source and to chemical weathering processes that occur (predominantly in soils) within the river catchment. The three principle Mo sources in the studied rivers are glacial ice $\left(\delta^{98 / 95} \mathrm{Mo}>1.8 \%\right.$ ), underlying bedrock ( $\delta^{98 / 95} \mathrm{Mo} \sim 0.0 \%$ ) and hydrothermal springs ( $\delta^{98 / 95} \mathrm{Mo} \sim-3.4 \%$ ). The isotopically heavy $\delta^{98 / 95}$ Mo composition inferred for glacial ice implies that, like other isotopic systems, Mo-isotopes are not significantly fractionated during evaporation, precipitation and freeze-thaw processes. The Deildartunguhver hydrothermal spring has the lightest $\delta^{98 / 95}$ Mo value measured to date, and although additional study is needed to verify whether this composition is truly representative of hydrothermal Mo, such extremely light values may reflect the non-stoichiometric partitioning of Mo-isotopes between oxic and sulphidic phases in hydrothermal fluids.

Samples of the dissolved phase taken from close to Vatnjökull glacier in southeast Iceland have the same isotope composition as the underlying bedrock, suggesting that rivers dominated by physical weathering processes and/or enhanced silicate mineral dissolution at high $\mathrm{pH}$ are not associated with resolvable Mo-isotope fractionation. In contrast, the dissolved Mo phase in the catchment area sampled in the west of Iceland displays a general increase in $\delta^{98 / 95} \mathrm{Mo}$ with distance from source (from $0.39 \%$ o to $1.01 \%$ ), which is thought to reflect the removal of light Mo-isotopes from the dissolved phase during weathering processes. The $\delta^{98 / 95}$ Mo composition of the particulate fraction (colloidal, bedload and Fe-precipitate) measured in a selection of samples shows that these phases are all isotopically lighter then the dissolved load, and may act as a sink for isotopically light Mo. However, the net offset between the dissolved load and the particulates remains constant throughout the river course, meaning that the adsorption of isotopically light Mo to particulate phases within the river cannot be driving the dissolved load to heavier $\delta^{98 / 95}$ Mo compositions. Most isotopically light Mo is therefore thought to be removed via adsorption and/or incorporation to secondary phases within soils, resulting in the addition of isotopically heavy groundwater to the river.

Most samples taken through the Borgarfjörour estuary in western Iceland display a simple mixing relationship between the river water and seawater end members, indicative of the conservative behaviour of Mo in the estuarine and marine environments. Waters from the low salinity mixing zone deviate slightly from this trend, however, as two estuarine samples have $\delta^{98 / 95} \mathrm{Mo}$ and [Mo] below that of the riverine input. This suggests that, in the Borgarfjörður estuary, at least, the salinity gradient may result in the release of isotopically light Mo from colloidal or particulate phase, and the simultaneous scavenging of dissolved Mo. Furthermore, mass balance of the different Mo-phases entering the ocean at Borgarfjörour estuary demonstrates that whilst Mo in the dissolved load is isotopically heavy (with respect to the weathered bedrock), the net isotopic offset from the lithogenic source may be considerably less if continued weathering of the colloidal and suspended phases in the marine environment is taken into consideration.

\section{Acknowledgements}

Anthony Cohen is thanked for analytical support, and colleagues at the Open University and at LMTG, Observatoiré de Midi Pyrénées, Toulouse are thanked for useful discussions. C. R. Pearce was supported by the National Environmental Research Council postdoctoral grant NE/B502701/1.

\section{References}

Anbar, A.D., 2004. Molybdenum stable isotopes: observations, interpretations and directions. In: Johnson, C. M., Beard, B., Albarède, F., (eds), Geochemistry of NonTraditional Stable Isotopes. Rev. Min. Geochem. 55, 429-454.

Andersson, P.S., Porcelli, D., Wasserburg, G.J., Ingri, J., 1998. Particle transport of U-234U-238 in the Kalix River and in the Baltic Sea. Geochim. Cosmochim. Acta 62 (3), 385-392.
Archer, C., Vance, D., 2008. The isotopic signature of the global riverine molybdenum flux and anoxia in the ancient oceans. Nat. Geosci. 1, 597-600.

Arnold, G.L., Anbar, A.D., Barling, J., Lyons, T.W., 2004. Molybdenum isotope evidence for widespread anoxia in mid-Proterozoic oceans. Science 304 (5667), 87-90.

Arnórsson, S., Óskarsson, N., 2007. Molybdenum and tungsten in volcanic rocks and in surface and $<100{ }^{\circ} \mathrm{C}$ ground waters in Iceland. Geochim. Cosmochim. Acta 71 (2), 284-304.

Barling, J., Anbar, A.D., 2004. Molybdenum isotope fractionation during adsorption by manganese oxides. Earth Planet. Sci. Lett. 217 (3-4), 315-329.

Barling, J., Arnold, G.L., Anbar, A.D., 2001. Natural mass-dependent variations in the isotopic composition of molybdenum. Earth Planet. Sci. Lett. 193 (3-4), 447-457.

Caritat, P., Hall, G., Gislason, S.R., Belsey, W., Braun, M., Goloubev, N.I., Olsen, H.K., Scheie, J.O., Vaive, J.E., 2005. Chemical composition of arctic snow: concentration levels and regional distribution of major elements. Sci. Tot. Env. 336, 183-199.

Colodner, D., Edmond, J., Boyle, E., 1995. Rhenium in the Black-Sea - comparison with Molybdenum and Uranium. Earth Planet. Sci. Lett. 131 (1-2), 1-15.

Dellwig, O., Beck, M., Lemke, A., Lunau, M., Kolditz, K., Schnetger, B., Brumsack, H.-J., 2007. Non-conservative behaviour of molybdenum in coastal waters: coupling geochemical, biological, and sedimentological processes. Geochim. Cosmochim. Acta 71 (11), 2745-2761.

Gannoun, A., Burton, K.W., Vigier, N., Gislason, S.R., Rogers, N.W., Mokadem, F., Sigfússon, B., 2006. The influence of weathering process on riverine osmium isotopes in a basaltic terrain. Earth Planet. Sci. Lett. 243 (3-4), 732-748.

Gaillardet, J., Dupre, B., Louvat, P., Allegre, C.J., 1999. Global silicate weathering and $\mathrm{CO}_{2}$ consumption rates deduced from the chemistry of large rivers. Chem. Geol. 159, 3-30.

Georg, R.B., Reynolds, B.C., West, A.J., Burton, K.W., Halliday, A.N., 2007. Silicon isotope variations accompanying basalt weathering in Iceland. Earth Planet. Sci. Lett. 261 (3-4), 476-490.

Gislason, S.R., Oelkers, E.H., 2003. The mechanism, rates and consequences of basaltic glass dissolution: II. An experimental study of the dissolution rates of basaltic glass as a function of pH and temperature. Geochim. Cosmochim. Acta 67 (20), 3817-3832.

Gislason, S.R., Arnorsson, S., Armannsson, H., 1996. Chemical weathering of basalt in southwest Iceland: effects of runoff, age of rocks and vegetative/glacial cover. Am. J. Sci. 296 (8), 837-907.

Gislason, S.R., Oelkers, E.H., Snorrason, A., 2006. Role of river-suspended material in the global carbon cycle. Geology 34, 49-52.

Gislason, S.R., Oelkers, E.H., Eiriksdottir, E.S., Kardjilov, M.I., Gisladottir, G., Sigfusson, B., Snorrason, A., Elefsen, S.O., Hardardottir, J., Torssander, P., Oskarsson, N., 2009. Direct evidence of the feedback between climate and weathering. Earth Planet. Sci. Lett. 277 (1-2), 213-222.

Hannah, J.L., Stein, H.J., Wieser, M.E., de Laeter, J.R., Varner, M.D., 2007. Molybdenum isotope variations in molybdenite: vapor transport and Rayleigh fractionation of Mo. Geology 35 (8), 703-706.

Jóhannesson, H., Saemundsson, K., 1998. Tectonic Map of Iceland 1:500, 000. Icelandic Institute of Natural History, Reykjavik, Iceland.

Johannesson, T., Thorsteinsson, T., Stefansson, A., Gaidos, E.J., Einarsson, B., 2007. Circulation and thermodynamics in a subglacial geothermal lake under the Western Skafta cauldron of the Vatnajokull ice cap, Iceland. Geophys. Res. Lett. 34 (19), L19502-L19504. doi:10.1029/2007GL030686.

Kawakubo, S., Ichikawa, S. Iwatsuki, M., 2002. Speciation of molybdenum in river water by size fractionation and catalytic determination. Anal. Sci. 18 (6), 651-654.

Kristmannsdóttir, H., Björnsson, A., Arnórsson, S., Ármannsson, H., Sveinbjörnsdóttir, Á.E., 2005. The Reykholt and Husafell Geothermal Fields in Borgarfjördur - A Geochemical Study. Proceedings World Geothermal Congress, Anatalya, Turkey.

Manheim, F.T., Landergren, S., 1974. Molybdenum. In: Wedepohl (Ed.), Handbook of Geochemistry. Springer-Verlag, New York.

Malinovsky, D., Hammarlund, D., Ilyashuk, B., Martinsson, O., Gelting, J., 2007. Variations in the isotopic composition of molybdenum in freshwater lake systems. Chem. Geol. 236 (3-4), 181-198.

McManus, J., Nägler, T.F., Siebert, C., Wheat, C.G., Hammond, D.E., 2002. Oceanic molybdenum isotope fractionation: diagenesis and hydrothermal ridge-flank alteration. Geochem. Geophys. Geosyst. 1078. doi:10.1029/2002 GC00035.

McManus, J., Berelson, W.M., Severmann, S., Poulson, R.L., Hammond, D.E., Klinkhammer, G.P., Holm, C., 2006. Molybdenum and uranium geochemistry in continental margin sediments: paleoproxy potential. Geochim. Cosmochim. Acta 70, 4643-4662.

Milliman, J.D., Syvitski, J.P.M., 1992. Geomorphic/tectonic control of sediment discharge to the ocean: the importance of small mountainous rivers. J. Geol. 100, 525-544.

Moorbath, S., Sigurdsson, H., Goodwin, R., 1968. K-Ar ages of the oldest exposed rocks in Iceland. Earth Planet. Sci. Lett. 4 (3), 197-205.

Morford, J.L., Emerson, S., 1999. The geochemistry of redox sensitive trace metals in sediments. Geochim. Cosmochim. Acta 63 (11-12), 1735-1750.

Neubert, N., Nägler, T.F., Böttcher, M.E., 2008a. Sulfidity controls molybdenum isotope fractionation into euxinic sediments: evidence from the modern Black Sea. Geology 36 (10), 775-778.

Neubert, N., Heri, A.R., Nägler, T.F., Böttcher, M.E., Villa, I.M., 2008b. Refining sources and sinks in the global molybdenum cycle. Geochim. Cosmochim. Acta 12, A676.

Neuhoff, P.S., Fridriksson, T., Arnorsson, S., Bird, D.K., 1999. Porosity evolution and mineral paragenesis during low-grade metamorphism of basaltic lavas at Teigarhorn, Eastern Iceland. Am. J. Sci. 299 (6), 467-501.

Oelkers, E.H., Pearce, C.R., Eiriksdottir, E.S., Gislason, S.R., 2009. The surface area, reactivity, and effect on global cycles of riverine transported basaltic suspended load. Geochim. Cosmochim. Acta 73 (13), A963.

Pearce, C.R., Cohen, A.S., Coe, A.L., Burton, K.W., 2008. Molybdenum isotope evidence for global ocean anoxia coupled with perturbations to the carbon cycle during the Early Jurassic. Geology 36 (3), 231-234. 
Pearce, C.R., Cohen, A.S., Parkinson, I.J., 2009. Quantitative separation of molybdenum and rhenium from geological materials for isotopic analysis by MC-ICP-MS Geostand. Geoanal. Res. 33 (2), 219-229.

Pett-Ridge, J., Siebert, C., Halliday, A.N., 2008. Molybdenum isotopes as proxy for redox conditions during weathering. Geochim. Cosmochim. Acta 72 (12), A741.

Pogge von Strandmann, P.A.E., Burton, K.W., James, R.H., van Calstren, P., Gislason, S.R., Mokadem, F., 2006. Riverine behaviour or uranium and lithium isotopes in an actively glaciated basaltic terrain. Earth Planet. Sci. Lett. 251 (1-2), 134-147.

Pogge von Strandmann, P.A.E., Burton, K.W., James, R.H., van Calstren, P., Gislason, S.R., Sigfússon, B., 2008a. The influence of weathering processes on riverine magnesium isotopes in a basaltic terrain. Earth Planet. Sci. Lett. 276 (1-2), 187-197.

Pogge von Strandmann, P.A.E., James, R.H., van Calstren, P., Gislason, S.R., Burton, K.W., 2008b. Lithium, magnesium and uranium isotope behaviour in the estuarine environment of basaltic islands. Earth Planet. Sci. Lett. 274 (3-4), 462-471.

Porcelli, D., Andersson, P.S., Wasserburg, G.J., Ingri, J., Baskaran, M., 1997. The importance of colloids and mires for the transport of uranium isotopes through the Kalix River watershed and Baltic Sea. Geochim. Cosmochim. Acta 61 (19), 4095-4113.

Poulson, R., Siebert, C., McManus, J., Berelson, W.M., 2006. Authigenic molybdenum isotope signatures in marine sediments. Geology 34 (8), 617-620.

Savenko, V.S., 1996. Physico-chemical state of molybdenum and tungsten in seawater (inorganic forms). Okeanologiya 36 (3), 384-389.

Siebert, C., McManus, J., Bice, A., Poulson, R., Berelson, W.M., 2006. Molybdenum isotope signatures in continental margin marine sediments. Earth Planet. Sci. Lett. 241 (3-4), 723-733.

Siebert, C., Nägler, T.F., von Blanckenburg, F., Kramers, J.D., 2003. Molybdenum isotope records as a potential new proxy for paleoceanography. Earth Planet. Sci. Lett. 211 (1-2), 159-171.
Siebert, C., Kramers, J.D., Meisel, T., Morel, P., Nagler, T.F., 2005. PGE, Re-Os, and Mo isotope systematics in Archean and early Proterozoic sedimentary systems as proxies for redox conditions of the early Earth. Geochim. Cosmochim. Acta 69 (7), 1787-1801.

Sigurdsson, F. Ingimarsson, J., 1990. The permeability of Icelandic rocks. In: Sigbjarnarson, G. (Ed.), The Water and the Land. Reykjavik, National Energy Authority.

Stefansdottir, M.B., Gislason, S.R., 2005. The erosion and suspended matter/seawater interaction during and after the 1996 outburst flood from the Vatnajokull Glacier. Iceland. Earth Planet. Sci. Lett. 237, 433-452.

Tossell, J.A., 2005. Calculating the partitioning of the isotopes of Mo between oxidic and sulfidic species in aqueous solution. Geochim. Cosmochim. Acta 69 (12) 2981-2993.

Vigier, N., Burton, K.W., Gislason, S.R., Rogers, N.W., Duchene, S., Thomas, L., Hodge, E. Schaefer, B., 2006. The relationship between riverine U-series disequilibria and erosion rates in a basaltic terrain. Earth Planet. Sci. Lett. 249 (3-4), 258-273.

Wieser, M.E., de Laeter, J.R., 2003. A preliminary study of isotope fractionation in molybdenites. Int. J. Mass Spec. 225 (2), 177-183.

Wille, M., Kramers, J.D., Nägler, T.F., Beukes, N.J., Schroder, S., Meiser, T., Lacassie, J.P. Voegelin, A.R., 2007. Evidence for a gradual rise of oxygen between 2.6 and $2.5 \mathrm{Ga}$ from Mo isotopes and Re-PGE signatures in shales. Geochim. Cosmochim. Acta 71 (10), 2417-2435.

Wolff-Boenisch, D., Gislason, S.R., Oelkers, E.H., 2006. The effect of crystallinity on dissolution rates and $\mathrm{CO}_{2}$ consumption capacity of silicates. Geochim. Cosmochim. Acta 70 (4), 858-870. 